\title{
FILOSOFIE DNES
}

Časopis pro současnou filosofii vydává KFSV FF UHK

\section{Šéfredaktor: Ladislav Koreň}

\section{Výkonná redaktorka: Iva Svačinová}

Redakční rada: Ondřej Beran, Jaroslav Daneš, Petr Glombíček, Tomáš Hirt, Juraj Hvorecký, Vojtěch Kolman, Ladislav Kvasz, Róbert Maco, Tomáš Marvan, Martin Paleček, Jaroslav Peregrin, Marie Hrdá, Ondřej Švec, Eugen Zeleňák

Editoři: Markéta Panoušková, Hynek Kaplan Sazba a grafická úprava: Hynek Kaplan

Adresa: Filosofie dnes, KFSV FF UHK Rokitanského 62 50003 Hradec Králové

E-mail: iva.svacinova@uhk.cz

vychází elektronicky, dvakrát ročně

www.filosofiednes.ff.uhk.cz

ISSN 1804-0969

Ročník 12, Č́́slo 2 (2020) 


\section{Obsah}

\section{Studie}

Kristýna Vozková José Ortega y Gasset a hispanoamerické filo3 sofické myšlení

Kristina Vejnbender Uplatnění pozdní filozofie L. Wittgensteina v myšlení C. Geertze

\section{Zprávy}

Lukáš Mareš

Filosofická praxe v České republice

Václav Peltan

Eliška Havlová

\section{Recenzní studie}

Jan Géryk

Politickofilosofický úklid v čase plurality

a zběsilé strnulosti.

Nad knihou Pavla Dufka, Jiř́ho Baroše,

Sylvie Bláhové, Terezy Křepelové a Patrika

Taufara Liberální demokracie $v$ době krize:

Perspektiva politické filosofie

Daniel D. Novotný Covid-19 katastrofa: Nad knihou Richarda Hortona 